\section{Effects of Fumigant Alternatives to Methyl Bromide on Pest Control in Open Field Nursery Production of Perennial Fruit and Nut Plants}

\author{
Sally M. Schneider ${ }^{1}$ and Bradley D. Hanson ${ }^{2,3}$
}

ADDITIONAL INDEX WORDs. 1,3-dichloropropene, chloropicrin, crop safety, iodomethane, preplant fumigation, root-knot nematode

SUMMARY. Nursery producers of perennial fruit and nut plants rely on preplant fumigation to meet regulatory requirements designed to ensure nematode-free planting stock. In the past, preplant treatments with methyl bromide or high rates of 1,3-dichloropropene were the preferred treatments. However, the phase out of methyl bromide due to environmental concerns and evolving regulations on the use of 1,3-dichloropropene has increased the need for effective and economical alternative fumigation treatments in open field nursery production. A field trial was conducted in a commercial nursery to test weed and nematode control with several tarped and untarped preplant applications of 1,3-dichloropropene, chloropicrin, and iodomethane in comparison with methyl bromide. Crop safety and nematode infestation were evaluated on a wide range of tree, vine, and berry nursery stock. No fall fumigation treatment in this study resulted in measurable injury to spring-planted nursery stock. There were few statistical differences between methyl bromide and the other fumigation treatments in crop establishment, crop quality, or nematode level at planting $\mathbf{5}$ months after treatment, although some untarped treatments had detectable levels of the root-knot nematode (Meloidogyne spp.). At grape (Vitus vinifera) and bramble (Rubus spp.) harvest after the first growing season, few statistical differences were noted in the number of nematodes isolated from roots; however, only methyl bromide had nondetectable levels in all varieties. The highest nematode levels were usually found in untarped iodomethane:chloropicrin and untarped chloropicrin plots. At tree harvest 26 months after fumigation, root-knot nematodes were isolated from the roots of highly susceptible tree varieties in several iodomethane:chloropicrin treatments and in chloropicrin alone plots. Untarped applications did not provide commercially acceptable control of weeds or root-knot nematode in this trial. Tarped applications of 30:70 and 50:50 iodomethane:chloropicrin provided nematode control similar to 1,3-dichloropropene, although not as good as methyl bromide. Iodomethane:chloropicrin combinations have been registered in other states and should be considered for use in California perennial fruit and nut crop nurseries as an alternative to methyl bromide.

Donations of fumigants and fumigation services from TriCal, Inc., Dow AgroSciences, and Arysta LifeScience Corporation, and the technical support of N. Goodell, C. Koga, and other Water Management Research Unit staff are gratefully acknowledged.

This article is a U.S. government work and is in the public domain in the USA. Mention of a trademark, proprietary product, or vendor does not constitute a guarantee or warranty of the product by the U.S. Department of Agriculture and does not imply its approval to the exclusion of other products or vendors that also may be suitable.

The authors wish to thank L.E. Cooke Company for donation of field space, planting stock, and crop management in this trial, and the Fruit Tree, Nut Tree, and Grapevine Improvement Advisory Board for financial support.

${ }^{1}$ U.S. Department of Agriculture, Agricultural Research Service, Crop Production and Protection, GWCC, Room 4-2218, Beltsville, MD 20705

${ }^{2}$ U.S. Department of Agriculture, Agricultural Research Service, 9611 South Riverbend Avenue, Parlier, CA 93648

${ }^{3}$ Corresponding author. E-mail: brad.hanson@ars.usda. gov. (CDFA), 2008a]. Alternatively, a alifornia phytosanitary regulations for fruit and nut plant nursery production require preplant fumigation with specified treatments for control of parasitic nematodes before nursery stock can be certified and sold [California
Department of Food and Agriculture robust set of nematode inspection procedures, including soil samples collected and composited on a $1 / 4$ acre basis in the field followed by nematode assessments on several hundred bare-root plants per acre at harvest, can be conducted in place of approved fumigation treatments. However, if economically important nematodes are found in the soil or on roots, the whole lot or block represented by that sample cannot be certified and sold for commercial farm planting (CDFA, 2008b). These regulations have been enacted to ensure that soil-borne pests and pathogens are not spread from infested field nurseries and that establishment and vigor of new fruiting fields is not compromised. For decades, preplant soil fumigation with methyl bromide $(\mathrm{MB})$ has been used in open field perennial fruit and nut crop nurseries to meet this regulation as well as to provide control of other soil-borne pests (Schneider et al., 2003). While parasitic nematodes are the primary pest target for fumigation in open field nurseries, weed control is an important consideration for producers because of relatively few selective herbicide choices and the high costs of hand weeding (Hanson and Schneider, 2008; Shrestha et al., 2008).

The production cycle for open field production of perennial fruit and nut crop nursery stock can vary considerably among crops and growers (Schneider et al., 2009). However, a common nursery production rotation includes a 1 -year fallow or cover crop, 1 or 2 years of rotational crops, and a 1 - to 3-year nursery crop. Because fruit and nut plants are subject to infection by a number of soil-borne pests, including the pathogens Pythium spp. and Verticillium dablia, parasitic nematodes such as lesion nematode (Pratylenchus spp.), rootknot nematode, and dagger nematode

\begin{tabular}{llll}
\hline $\begin{array}{l}\text { Units } \\
\begin{array}{l}\text { To convert U.S. to SI, } \\
\text { multiply by }\end{array}\end{array}$ & U.S. unit & SI unit & $\begin{array}{l}\text { To convert SI to U.S., } \\
\text { multiply by }\end{array}$ \\
\hline 0.4047 & $\mathrm{acre}(\mathrm{s})$ & $\mathrm{ha}$ & 2.4711 \\
0.3048 & $\mathrm{ft}$ & $\mathrm{m}$ & 3.2808 \\
2.54 & inch(es) & $\mathrm{cm}$ & 0.3937 \\
16.3871 & inch $^{3}$ & $\mathrm{~cm}^{3}$ & 0.0610 \\
1.1209 & lb/acre & ${\mathrm{kg} \cdot h a^{-1}}^{3}$ & 0.8922 \\
1 & micron & $\mu \mathrm{m}$ & 1 \\
25.4 & mil & $\mu \mathrm{m}$ & 0.0394 \\
28.3495 & $\mathrm{Oz}$ & $\mathrm{g}$ & 0.0353 \\
$\left({ }^{\circ} \mathrm{F}-32\right) \div 1.8$ & ${ }^{\circ} \mathrm{F}$ & ${ }^{\circ} \mathrm{C}$ & $\left(1.8 \times{ }^{\circ} \mathrm{C}\right)+32$
\end{tabular}


(Xiphinema spp.), and competition from a wide range of weeds (Duniway, 2002, Dreistadt, 2001; Schneider et al., 2003, 2009; Shrestha et al., 2008), most open field nurseries in California are fumigated in the summer before planting the nursery crop. Although MB was phased out under the terms of the Montreal Protocol because of its deleterious effects on stratospheric ozone, this compound is still the most commonly used soil treatment for certified nursery production in California and is allowed under critical use exemption (CUE) and quarantine/preshipment (QPS) criteria [United Nations Environment Programme (UNEP), 1999].

Alternatives to $\mathrm{MB}$ are needed by producers of perennial fruit and nut crop nursery stock to produce highquality plants that meet clean planting material requirements while minimizing adverse impacts on stratospheric ozone. Alternative fumigants have been tested in many cropping systems (Ruzo, 2005; Schneider et al., 2003) with varying degrees of successful adoption by growers (Trout, 2006). Perennial fruit and nut crop nurseries can provide a difficult test of otherwise effective alternative fumigants because the extremely low tolerance for nematode infestation and relatively long growing cycle require pest control efficacy at soil depths of $5 \mathrm{ft}$ or greater (Schneider et al., 2009).

Compared with $\mathrm{MB}$, many potential alternatives provide consistent control over a narrower spectrum of pests and pathogens and are more sensitive to soil conditions (Duniway, 2002). For some soil texture and soil moisture conditions, 1,3-dichloropropene $(1,3-\mathrm{D})$ is an approved soil treatment for certified nursery production in California (CDFA, 2008a). However, the maximum use rate of $1,3-\mathrm{D}$ in California (332 $\mathrm{lb} / \mathrm{acre})$ does not provide sufficient nematode control in nurseries with fine-textured soils (McKenry, 2005). The use of 1,3-D in California is further restricted by township caps that are shared by all 1,3-D-using crops on a first-come-first-served basis [California Department of Pesticide Regulation (CDPR), 2002]. Metam sodium and chloropicrin (Pic) are currently registered in the United States and have provided nematode, pathogen, or weed control in trials in various production systems (De Cal et al., 2004;
Gilreath et al., 2005; Mann et al., 2005 ) but are not currently approved for certified nursery production in California. Iodomethane [IM (previously called methyl iodide)], which was recently registered for use in much of the United States, is still under review by the California Environmental Protection Agency. IM has shown promise in open field nursery trials, as well as other trials (Becker et al., 1998; Eayre et al., 2000; Schneider et al., 2005; Shrestha et al., 2008).

The objective of the trial reported here was to evaluate pest control efficacy and crop safety with several registered and experimental alternatives to $\mathrm{MB}$ in a diverse perennial fruit and nut crop open field nursery.

\section{Materials and methods}

A trial was initiated in 2001 in a commercial nursery near Visalia, CA, in a field known to have significant levels of root-knot nematode. The previous corn (Zea mays) crop was removed in Sept. 2001 and the field was prepared using standard commercial practices. The field included two soil types: a Grangeville sandy loam ( $\mathrm{pH} 7.2$, organic matter $0.6 \%$ ) and a Nord fine sandy loam $(\mathrm{pH} 7.5$, organic matter 0.9\%). Fumigant treatments included $\mathrm{MB}$, Pic, and premix combinations of $61 \% \quad 1,3-$ D:35\% Pic (1,3-D:Pic), 30\% iodomethane:70\% Pic (IM:Pic 30:70), and $50 \%$ iodomethane:50\% chloropicrin (IM:Pic 50:50) (Table 1). The MB plots were sealed with a 1-mil highdensity polyethylene (HDPE) tarpaulin. Each MB alternative was applied with (tarped) and without (untarped) HDPE. Each treatment combination and an untreated control were included in four blocks in a randomized complete block design with $22 \times 100$ $\mathrm{ft}$ individual plots. All treatments were shank-injected and were applied by a commercial applicator (Tri-Cal, Hollister, CA) on 23 Oct. 2001. A Noble plow rig was used to apply all tarped treatments at a depth of 12 inches and simultaneously install the HDPE in a single operation. The deep shank rig used for untarped IM had a 20-inch injection depth and shank spacing of $5.5 \mathrm{ft}$ while the Telone rig used for the untarped 1,3-D:Pic and Pic treatments had shanks spaced 20 inches apart and a
20 -inch injection depth. Soil temperature at the time of fumigation was $66^{\circ} \mathrm{F}$ at 12 inches and soil moisture ranged from $10.0 \%$ to $11.3 \%(\mathrm{w} / \mathrm{w})$ from the surface to a depth of $5 \mathrm{ft}$. HDPE tarps were removed $7 \mathrm{~d}$ after fumigation.

Ten tree, nine grape, and five bramble nursery crops were planted in single-row subplots between 13 March and 4 Apr. 2002 (Table 2). Tree cuttings or seed and bramble cuttings were planted in 10 -ft subplots with 16 to 20 plants per plot, and grape cuttings were planted in 6 -ft subplots with 11 to 14 plants per plot. Rows were spaced $6 \mathrm{ft}$ apart, and each fumigation main plot had two rows of trees and one row each of grape and bramble nursery stock.

At planting, soil samples were collected with a 3-inch-diameter bucket auger from the center of each plot in 12-inch increments to a depth of $5 \mathrm{ft}$. Soil samples were thoroughly mixed and a $250-\mathrm{cm}^{3}$ subsample was extracted using the sieving/Baermann funnel protocol that recovers only those nematodes that could be viable as plant parasites (Flegg and Hooper, 1970; Barker, 1985). The nematodes in each sample were identified and counted under a microscope and the data were standardized to a $100-\mathrm{cm}^{3}$ volume of soil. Nematode counts were transformed using $[\ln (\mathrm{x}$ $+1)$ ] to stabilize the variance (Noe, 1985); however, data presented are antilogs of the means. Nematode control, weed control, plant vigor, and harvest data were analyzed using analysis of variance (ANOVA) and treatment means were separated by Fisher's protected least significant difference procedure at $P<0.05$ (SAS version 9.1; SAS Institute, Cary, NC).

In Oct. 2002, established plants were counted in each tree, vine, and bramble subplot, and the data were converted to percentage of establishment. Relative weed control was evaluated in Mar. 2002 (before planting) and in Oct. 2003, which was 5 and 24 months after treatment (MAT), respectively. Weed pressure at each date was scored on a 0 (no weeds observed) to 5 (solid mat of weeds in the plant row) weed control index.

In Dec. 2002, soil samples were collected with a 1 -inch-diameter sampling tube to a depth of 24 inches in each of the grape and bramble 
Table 1. Fumigation treatments in a perennial fruit and nut plant open-field nursery trial established in 2001 near Visalia, CA.

\begin{tabular}{|c|c|c|c|}
\hline Treatment $^{\mathrm{z}}$ & Formulation & Rate $(1 b / a c r e ~ a . i .)^{y}$ & Application equipment ${ }^{\mathrm{x}}$ \\
\hline Untreated & - & - & - \\
\hline $\mathrm{MB}$, tarped & $98 \%$ methyl bromide: $2 \%$ chloropicrin & 512 & Noble plow rig \\
\hline 1,3-D:Pic, untarped & $61 \%$ 1,3-dichloropropene: $35 \%$ chloropicrin & 334 & Telone rig \\
\hline 1,3-D:Pic, tarped & $61 \%$ 1,3-dichloropropene: $35 \%$ chloropicrin & 381 & Noble plow rig \\
\hline IM:Pic 30:70, untarped & $30 \%$ iodomethane: $70 \%$ chloropicrin & 400 & Deep shank rig \\
\hline IM:Pic 30:70, tarped & $30 \%$ iodomethane: $70 \%$ chloropicrin & 427 & Noble plow rig \\
\hline Pic, untarped & $99 \%$ chloropicrin & 358 & Telone rig \\
\hline Pic, tarped & $99 \%$ chloropicrin & 475 & Noble plow rig \\
\hline
\end{tabular}

${ }^{2} \mathrm{MB}=$ methyl bromide, $1,3-\mathrm{D}=1,3$-dichloropropene, $\mathrm{Pic}=$ chloropicrin, $\mathrm{IM}=$ iodomethane, tarped = covered with high density polyethylene $(\mathrm{HDPE})$ film, untarped = no HDPE film.

'Fumigant rates shown are based on fumigant cylinder weights taken before and after treating each plot. Actual rates varied from target rates due to pass-to-pass variability inherent in using large equipment on relatively small experimental plots; $1 \mathrm{lb} / \mathrm{acre}=1.1209 \mathrm{~kg} \cdot \mathrm{ha}^{-1}$.

${ }^{x}$ Noble plow rig was configured to inject fumigants at a 12 -inch $(30.5 \mathrm{~cm})$ depth through nozzles spaced 12 inches apart while simultaneously installing a 1 -mil $(25.4 \mu \mathrm{m})$ HDPE tarp. The Telone rig was set up to inject fumigants at a 20 -inch $(50.8 \mathrm{~cm})$ depth through shanks spaced 20 inches apart. The deep shank rig used for IM:Pic treatments injected the fumigants at a 20 -inch depth through shanks spaced $5.5 \mathrm{ft}(1.68 \mathrm{~m})$ apart.

Table 2. Tree, grape, and bramble nursery stock planted in subplots in an open field perennial nursery crop fumigation trial near Visalia, CA. Fumigation treatments were applied in Oct. 2001 and nursery stock was planted in March and Apr. 2002.

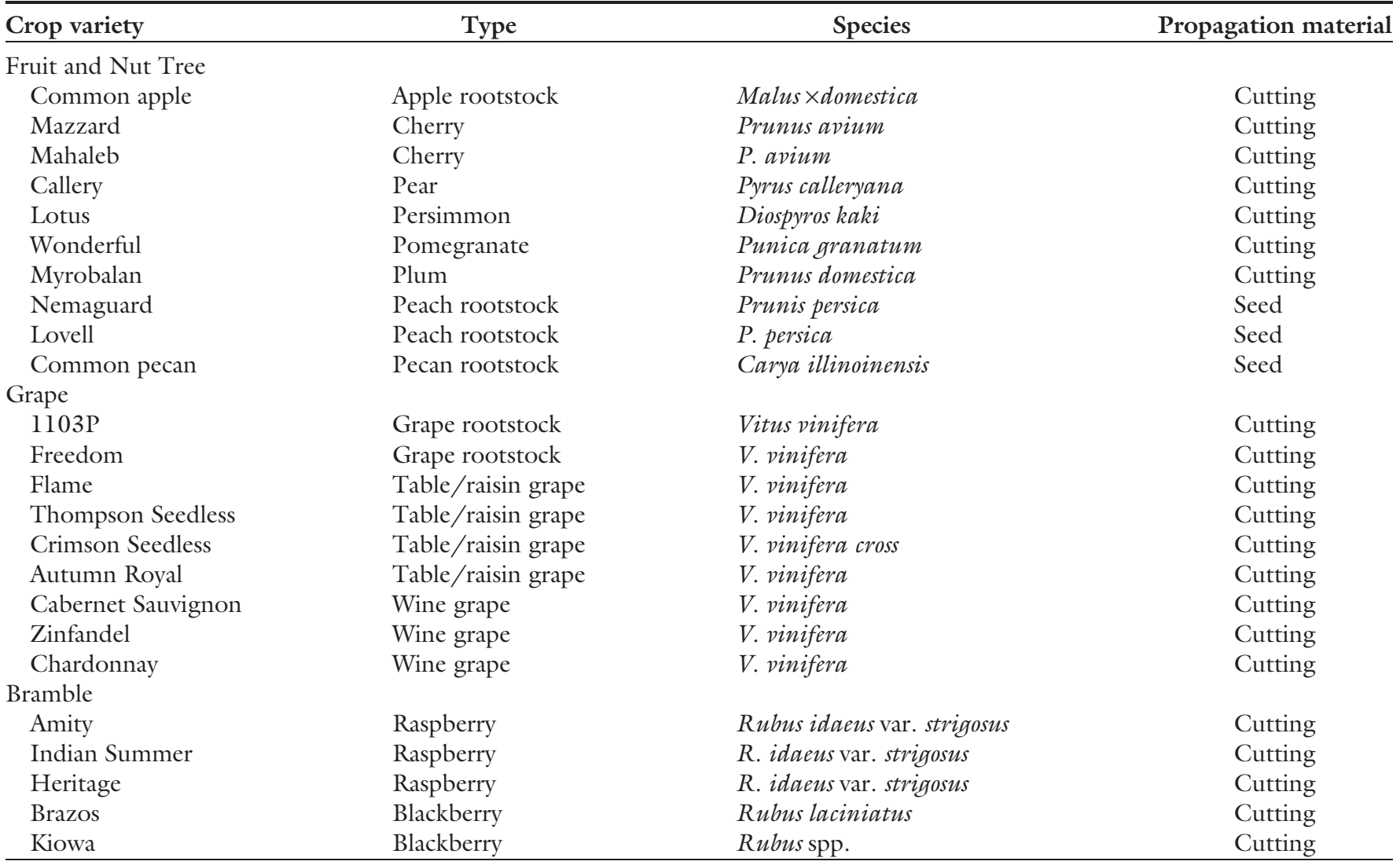

subplots and nematodes were extracted from a $250-\mathrm{cm}^{3}$ subsample using the sieving/sugar flotation/ centrifugation protocol with a 500 mesh sieve (25- $\mu$ m opening) (Barker, 1985; Jenkins, 1964). Grape and bramble plants were mechanically harvested in Dec. 2002 (9 months after planting, 14 MAT) and were evaluated according to commercial nursery standards into two saleable categories (\#1 and \#2) and nonsalable plants. During harvest, a representative root sample was collected in each subplot and a 20-g subsample was removed and processed for nematode extraction using the mist chamber protocol for $5 \mathrm{~d}$ (Barker, 1985).
Data were analyzed as previously described.

In Dec. 2003, near the end of the second growing season, soil samples were collected in each fruit and nut tree subplot, and nematodes were extracted and evaluated as previously described. All trees were mechanically harvested and evaluated for vigor and 
quality. Trunk diameter was measured and each root system was visually assessed for galling. Root samples were collected and a 20 -g subsample was removed for nematode evaluation and processed as previously described.

\section{Results}

Before planting the nursery crop in Mar. 2002, weed density was highest in the unfumigated plots and lowest in all tarped treatments except tarped Pic (Table 3). Untarped treatments and tarped Pic had intermediate weed densities that generally consisted of winter annual weeds such as mallow (Malva spp.), fiddleneck (Amsinkia spp.), fillaree (Erodium spp.), and annual bluegrass (Poa annua). Although not statistically significant, these trends in weed control were still present 18 months later, before harvest of the tree varieties (data not shown).

The predominant parasitic nematode found in the samples collected at planting was root-knot nematode. Root-knot nematode levels were significantly higher at all depths in the untreated control compared with all other treatments (Table 3). Nematode levels in all chemical treatments were statistically the same as $\mathrm{MB}$ at all depths except for IM:Pic 50:50, at 0 to 12 inches. Although not always statistically different from zero, detectable levels of nematodes were observed at planting in the top 12 inches of the two untarped IM: Pic treatments and in the lower depths of the tarped 1,3-D:Pic, IM:Pic 50:50 untarped, and tarped Pic treatments.

The seeded peach (Prunis persica) rootstocks 'Nemaguard' and 'Lovell' are usually planted in the fall, and these two species did not establish in any plots, most likely due to inadequate vernalization of the seed following planting in March. In Oct. 2002, there were no statistical differences in the number of established tree, vine, or bramble varieties among treatments $(P=0.05)$. There was also no clear benefit of the tarped fumigant applications on crop establishment. However, plant survival varied greatly among replications in some species, which may have masked any effects of fumigation treatment.

At grape and bramble harvest in Dec. 2002, there were no statistical differences in average grape trunk diameter among treatments (data not shown), although substantial natural variability in plant size within a subplot was noted. There were few effects on the grade of either bramble plants or grapevines that could be attributed to fumigation treatment. When differences in commercial grade were observed, it was usually due to an increase in low-grade plants in the unfumigated plots compared with all fumigation treatments rather than differences among fumigation treatments and was highly correlated to root galling from nematode activity (see below).

The patchy nature of root-knot nematode populations resulted in a significant $(P=0.05)$ treatment by replicate interaction for most vine and bramble species, making statistical separations of root infestation at harvest difficult. However, substantial numbers of root-knot nematodes were recovered from the roots of most grape varieties in plots treated with untarped IM:Pic (both formulations) and untarped Pic (Table 4). A few highly susceptible grape and bramble varieties also hosted low levels of the root-knot nematode in other treatments as well (Table 4). Similar trends were observed for the five bramble varieties (data not shown). Levels of root-knot and other nematodes isolated from the soil samples followed the same general trends as shown for the root-knot nematodes isolated from roots and are not presented here.

After an additional growing season to reach marketable size, fruit and nut tree nursery stock was

Table 3. Relative weed index immediately before planting and root-knot nematode populations at planting in a perennial fruit and nut plant open field nursery trial near Visalia, CA. Fumigation treatments were applied in Oct. 2001 and weed evaluations and nursery crop planting occurred in March and Apr. 2002.

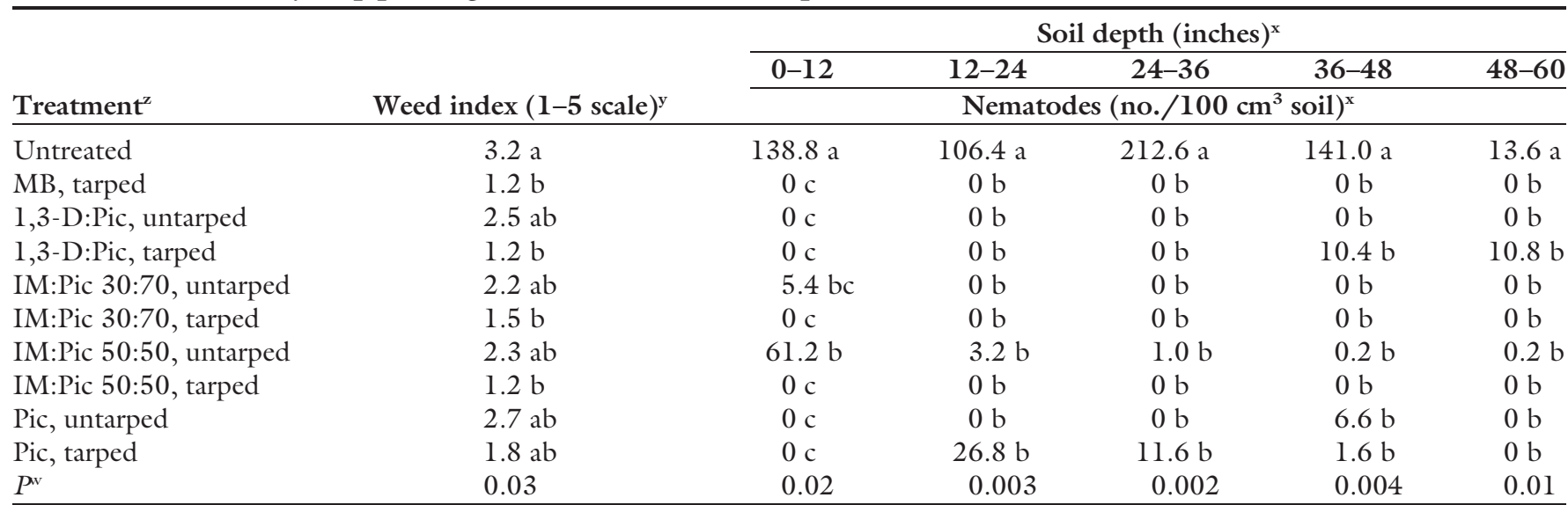

${ }^{2}$ Treatments are detailed in Table 1 and included: MB:Pic, tarped $=98 \%$ methyl bromide: $2 \%$ chloropicrin at $512 \mathrm{lb} /$ acre $\left(1 \mathrm{lb} /\right.$ acre $\left.=1.1209 \mathrm{~kg} \cdot \mathrm{ha}{ }^{-1}\right) ; 1,3-\mathrm{D}:$ Pic, untarped $=$ 61\% 1,3-dichloropropene:35\% chloropicrin at $334 \mathrm{lb} /$ acre; 1,3-D:Pic; 1,3-D:Pic, tarped = 61\% 1,3-dichloropropene:35\% chloropicrin at 381 lb/acre; IM:Pic 30/70, untarped $=30 \%$ iodomethane: $70 \%$ chloropicrin at $400 \mathrm{lb} /$ acre; IM:Pic 30/70, tarped $=30 \%$ iodomethane:70\% chloropicrin at $427 \mathrm{lb} /$ acre; IM:Pic $50 / 50$, untarped $=50 \%$ iodomethane: $50 \%$ chloropicrin at $367 \mathrm{lb} /$ acre; IM:Pic 50/50, tarped $=50 \%$ iodomethane: $50 \%$ chloropicrin at $358 \mathrm{lb} /$ acre; Pic, untarped $=99 \%$ chloropicrin at $358 \mathrm{lb} /$ acre; Pic, tarped $=99 \%$ chloropicrin at $475 \mathrm{lb} /$ acre; tarped $=$ covered with high-density polyethylene (HDPE) film; untarped = no HDPE film.

$\mathrm{y}_{0}=$ no visible weeds, 5 = solid mat of weeds in plant row

${ }^{\mathrm{x}} 1$ inch $=2.54 \mathrm{~cm}, \mathrm{l}$ nematode $/ 100 \mathrm{~cm}^{3}=0.1639$ nematode $/$ inch $^{3}$

wStatistical analyses conducted on $\log$-transformed $[\ln (n+1)]$ data; however, data presented are the means of the untransformed values. Means followed by the same letter within a column are not significantly different at the $P=0.05$ level according to Fisher's protected least significant difference (LSD) procedure. 
harvested in Dec. 2003 (21 months after planting; 26 MAT). No phytotoxicity was observed for any treatment/tree species combination. At harvest, trees were divided into 11 trunk diameter sizes ranging from $1 / 4$ to 2 inches. No significant differences in trunk size distribution among treatments were observed for any tree variety nor were any consistent trends with respect to presence or absence of a tarp noted (data not shown).
Similar to the vine and bramble harvest data from 2002, there was a significant treatment by replication interaction in root-knot nematode levels in the tree subplots $(P=0.05)$. This again made it difficult to statistically differentiate among levels of root-knot nematodes isolated from soil or tree roots. However, no nematodes were detected on tree roots from the $\mathrm{MB}$, untarped 1,3-D:Pic, or tarped IM:Pic 30:70 treatments (Table 5). Conversely, low to moderate levels of root-knot nematodes were noted in every tree variety except apple (Malus $\times$ domestica) in the untreated plots. Compared with the other tree varieties, 'Wonderful' pomegranate (Punica granatum) appeared to be more susceptible to root-knot nematode infestation. Levels of root-knot nematodes isolated from soil samples followed the same trends as shown for nematodes isolated from roots and are not presented.

Table 4. Root-knot nematode population on roots of nursery grapevines harvested 9 months after planting in an open field perennial crop nursery trial near Visalia, CA. Fumigation treatments were applied in Oct. 2001; vines were planted in Mar. 2002 and harvested in Dec. 2002.

\begin{tabular}{|c|c|c|c|c|c|c|c|c|c|}
\hline \multirow[b]{2}{*}{ Treatment $^{\mathrm{z}}$} & '1013P' & 'Freedom' & 'Flame' & $\begin{array}{l}\text { 'Thompson } \\
\text { Seedless' }\end{array}$ & $\begin{array}{l}\text { 'Crimson } \\
\text { Seedless' }\end{array}$ & $\begin{array}{l}\text { 'Autumn } \\
\text { Royal' }\end{array}$ & $\begin{array}{l}\text { 'Cabernet } \\
\text { Sauvignon' }\end{array}$ & 'Zinfandel' & 'Chardonnay' \\
\hline & \multicolumn{9}{|c|}{ Nematodes $(\text { no. } / 20 \text { g roots })^{\mathrm{y}}$} \\
\hline Untreated & 13.0 & 208.0 & $377.5 \mathrm{a}$ & 424.0 & 269.0 & 83.0 & 542.5 & 545.5 & 507.5 \\
\hline $\mathrm{MB}$, tarped & 0 & 0 & $0 \mathrm{c}$ & 0 & 0 & 0 & 0 & 0 & 0 \\
\hline 1,3-D:Pic, untarped & 0 & 0 & $31.5 \mathrm{bc}$ & 43.0 & 0 & 0 & 0 & 0 & 0 \\
\hline 1,3-D:Pic, tarped & 0 & 0 & $0 \mathrm{c}$ & 0 & 4.5 & 83.0 & 26.0 & 0 & 0 \\
\hline IM:Pic 50:50, untarped & 0 & 0 & $16.0 \mathrm{~b}$ & 25.3 & 26.0 & 46.0 & 13.3 & 30.7 & 3.3 \\
\hline IM:Pic 50:50, tarped & 0 & 0 & $0 \mathrm{c}$ & 4.5 & 1.5 & 1.0 & 0 & 0 & 0 \\
\hline Pic, untarped & 0 & 0 & $594.5 \mathrm{a}$ & 61.5 & 7.5 & 26.5 & 158.0 & 124.5 & 379.5 \\
\hline Pic, tarped & 0 & 0 & $0 \mathrm{c}$ & 0 & 0 & 0 & 7.3 & 1.3 & 0 \\
\hline$P^{\mathrm{N}}$ & 0.16 & 0.14 & 0.03 & 0.10 & 0.07 & 0.32 & 0.30 & 0.11 & 0.42 \\
\hline
\end{tabular}

${ }^{2}$ Treatments are detailed in Table $\mathrm{l}$ and included: MB:Pic, tarped $=98 \%$ methyl bromide: $2 \%$ chloropicrin at $512 \mathrm{lb} / \mathrm{acre}\left(1 \mathrm{lb} / \mathrm{acre}=1.1209 \mathrm{~kg} \cdot\right.$ ha $\left.{ }^{-1}\right) ; 1,3-\mathrm{D}:$ Pic, untarped $=$ 61\% 1,3-dichloropropene:35\% chloropicrin at $334 \mathrm{lb} / \mathrm{acre} ; 1,3$-D:Pic, tarped = 61\% 1,3-dichloropropene:35\% chloropicrin at 381 lb/acre; IM:Pic 30/70, untarped = 30\% iodomethane:70\% chloropicrin at $400 \mathrm{lb} /$ acre; IM:Pic 30/70, tarped $=30 \%$ iodomethane: $70 \%$ chloropicrin at $427 \mathrm{lb} /$ acre; IM:Pic $50 / 50$, untarped = 50\% iodomethane:50\% chloropicrin at $367 \mathrm{lb} /$ acre; IM:Pic 50/50, tarped = 50\% iodomethane:50\% chloropicrin at $358 \mathrm{lb} /$ acre; Pic, untarped = 99\% chloropicrin at $358 \mathrm{lb} /$ acre; and Pic, tarped = 99\% chloropicrin at $475 \mathrm{lb} /$ acre; tarped = covered with high-density polyethylene (HDPE) film; untarped = no HDPE film.

y nematode $/ 20 \mathrm{~g}=1.4175$ nematode $/ \mathrm{oz}$

${ }^{x}$ Statistical analyses conducted on $\log$-transformed $[\ln (n+1)]$ data; however data presented are the means of the untransformed values. Means followed by the same letter within a column are not significantly different at the $P=0.05$ level according to Fisher's protected least significant difference (LSD) procedure.

Table 5. Root-knot nematode population on roots of nursery trees harvested 26 months after treatment in an open field perennial crop nursery fumigation trial near Visalia, CA. Fumigation treatments were applied in Oct. 2001; trees were planted in Mar. 2002 and harvested in Dec. 2003.

\begin{tabular}{|c|c|c|c|c|c|c|c|c|}
\hline \multirow[b]{2}{*}{ Treatment $^{\mathrm{z}}$} & $\begin{array}{c}\text { 'Callery' } \\
\text { pear }\end{array}$ & $\begin{array}{l}\text { Common } \\
\text { apple }\end{array}$ & $\begin{array}{c}\text { 'Lotus' } \\
\text { persimmon }\end{array}$ & $\begin{array}{c}\text { 'Mahaleb' } \\
\text { cherry }\end{array}$ & $\begin{array}{l}\text { 'Mazzard' } \\
\text { cherry }\end{array}$ & $\begin{array}{c}\text { 'Myrobalan' } \\
\text { plum }\end{array}$ & $\begin{array}{c}\text { Common } \\
\text { pecan }\end{array}$ & $\begin{array}{l}\text { 'Wonderful' } \\
\text { pomegranate }\end{array}$ \\
\hline & \multicolumn{8}{|c|}{ Nematodes $(\text { no. } / 20 \text { g roots })^{\mathrm{y}}$} \\
\hline Untreated & 1.0 & 0 & 33.5 & 6.0 & 2.5 & 12.5 & 3.5 & 382 \\
\hline $\mathrm{MB}$, tarped & 0 & 0 & 0 & 0 & 0 & 0 & 0 & 0 \\
\hline 1,3-D:Pic, untarped & 0 & 0 & 0 & 0 & 0 & 0 & 0 & 0 \\
\hline 1,3-D:Pic, tarped & 0 & 0 & 0 & 0 & 0 & 0 & 0 & 4.0 \\
\hline IM:Pic 50:50, untarped & 0 & 0 & 0 & 4.7 & 0 & 0 & 0 & 0 \\
\hline IM:Pic 50:50, tarped & 0 & 0 & 3.5 & 1.5 & 0 & 0 & 0 & 6.5 \\
\hline Pic, untarped & 0 & 0 & 5.5 & 0 & 0 & 0 & 0 & 4.0 \\
\hline Pic, tarped & 0 & 0 & 0 & 0 & 0 & 1.3 & 0 & 166.7 \\
\hline$P^{\mathrm{N}} \mathrm{P}^{-1}$ & 0.92 & - & 0.26 & 0.25 & 0.28 & 0.32 & 0.92 & 0.77 \\
\hline
\end{tabular}

${ }^{2}$ Treatments are detailed in Table 1 and included: MB:Pic, tarped $=98 \%$ methyl bromide: $2 \%$ chloropicrin at $512 \mathrm{lb} / \mathrm{acre}\left(1 \mathrm{lb} / \mathrm{acre}=1.1209 \mathrm{~kg} \cdot \mathrm{ha}{ }^{-1}\right) ; 1,3-\mathrm{D}:$ Pic, untarped $=$ 61\% 1,3-dichloropropene:35\% chloropicrin at $334 \mathrm{lb} /$ acre; 1 ,3-D:Pic, tarped $=61 \% \mathrm{l}, 3$-dichloropropene:35\% chloropicrin at $381 \mathrm{lb} /$ acre; IM:Pic $30 / 70$, untarped = 30\% iodomethane: $70 \%$ chloropicrin at $400 \mathrm{lb} /$ acre; IM:Pic 30/70, tarped = 30\% iodomethane:70\% chloropicrin at $427 \mathrm{lb} /$ acre; IM:Pic $50 / 50$, untarped = 50\% iodomethane:50\% chloropicrin at $367 \mathrm{lb} /$ acre; IM:Pic 50/50, tarped = 50\% iodomethane:50\% chloropicrin at $358 \mathrm{lb} /$ acre; Pic, untarped $=99 \%$ chloropicrin at $358 \mathrm{lb} /$ acre; and Pic, tarped $=99 \%$ chloropicrin at $475 \mathrm{lb} /$ acre; tarped $=$ covered with high-density polyethylene (HDPE) film; untarped = no HDPE film

${ }^{y} 1$ nematode $/ 20 \mathrm{~g}=1.4175$ nematode $/ \mathrm{oz}$

${ }^{x}$ Statistical analyses conducted on $\log$ transformed $[\ln (n+1)]$ data; however, data presented are the means of the untransformed values. 


\section{Discussion}

The results of this trial suggest that there is an adequate level of crop safety for spring-planted nursery crops following fall fumigation with IM:Pic and 1,3-D:Pic treatments; the safety of fall planted nursery crops to these treatments was not tested. Weed and root-knot nematode control generally was better in tarped treatments compared with untarped. Weed and shallow nematode control may have been enhanced by tarped applications due to increased retention of the fumigant in the shallow soil layers resulting in an adequate time-concentration dose of the fumigant (Wang et al., 2004). Additionally, the tarped treatments were all applied with the Noble plow rig (12inch injection depth, 12-inch nozzle spacing), whereas the untarped treatments were applied at a 20 -inch depth through nozzles spaced 20 (Telone rig) or 66 (deep shank rig) inches apart, which likely affected fumigant distribution through the soil profile. If untarped fumigant applications are used in perennial fruit and nut crop nurseries, additional control strategies such as herbicides and nematicides likely will be required to control pests near the soil surface (Hanson and Schneider, 2008; McKenry, 2005).

Deeper application of the alternative fumigants (Telone rig or deep shank with 20-inch injection versus Noble plow with 12 -inch injection) often resulted in better nematode control at the lower soil depths. For example, shallow-injected 1,3-D:Pic (tarped, Noble plow application) likely did not result in a sufficient fumigant concentration at the 36- to 60-inch depth to completely control nematodes, as has been documented in other cropping systems (Westphal et al., 2004).

Under the conditions of this trial, no untarped application of any alternative fumigant provided a sufficient level of nematode control for the California nursery industry. While several of the tarped treatments provided root-knot nematode control that was statistically similar to $\mathrm{MB}$, only $\mathrm{MB}$ consistently reduced nematode levels below detection limits. Tarped applications of IM:Pic (both formulations) and Pic provided rootknot nematode suppression at least as good as tarped 1,3-D:Pic, which is already approved for California nursery use in some soil types; thus, these alternatives should be considered for regulatory approval in this industry.

Although many high-value agricultural sectors in the United States and around the world have historically relied on preplant fumigation with $\mathrm{MB}$, the perennial fruit and nut plant nursery industry faces a comparatively difficult transition to alternative pest control strategies. This industry group must meet stringent phytosanitary requirements to ship and sell their crop interstate and internationally. Economic thresholds for nematode or disease infestations that may be used in decision making in other commodities are not applicable to producers of nursery stock. In nursery cropping systems, the standard for certification of the harvested crop is "below detection." If root-knot or other parasitic nematodes are detected in harvested plants, the result may be $100 \%$ crop loss (nonsaleable crop) in that field or management unit. Additionally, long growing cycles ( $1-3$ years in some cases) require very effective nematode control deep into the soil profile to delay reinfestation before harvest. Finally, the diversity of nursery crop species, rootstock/scion combinations, and cultural practices, as well as the high value of the crop, require substantial crop safety research before growers can be expected to adopt an alternative treatment. Considerable research on alternative fumigants, fumigant application systems, and cropping systems, as well as changes in state and federal regulations related to nursery stock certification and environmental quality are needed before this industry can completely transition away from $\mathrm{MB}$ use.

\section{Literature cited}

Barker, K.R. 1985. Nematode extraction and bioassays, p. 19-35. In: K.R. Barker, C.C. Carter, and J.N. Sasser (eds.). An advanced treatise on Meloidogyne volume II: Methodology. North Carolina State University Graphics, Raleigh, NC.

Becker, J.O., H.D. Ohr, N.M. Grech, M.E. McGiffen, Jr., and J.J. Sims. 1998 Evaluation of methyl iodide as a soil fumigant in container and small field plot studies. Pestic. Sci. 52:58-62.

California Department of Food and Agriculture (CDFA). 2008a. Approved treatment and handling procedures to ensure against nematode pest infestation of nursery stock. Nursery inspection procedures manual, Item \#7. 23 Dec. 2008. <http:// www.cdfa.ca.gov/phpps/PE/Nursery/ pdfs/NIPM_7.pdf>.

California Department of Food and Agriculture (CDFA). 2008b. Sampling procedures and techniques for detection of nematodes by laboratory examination. Nursery inspection procedures manual, Item \#7.1. 23 Dec. 2008. <http:// www.cdfa.ca.gov/phpps/PE/Nursery/ pdfs/nipm_7_1.pdfs

California Department of Pesticide Regulation (CDPR). 2002. California management plan: 1,3-Dichloropropene. 17 Nov. 2008. <http://www.cdpr.ca.gov/docs/ emon/methbrom/telone/mgmtplan.pdfs.

De Cal, A., A. Martinez-Treceno, J.M. Lopez-Aranda, and P. Melgarejo. 2004. Chemical alternatives to methyl bromide in Spanish strawberry nurseries. Plant Dis. $88: 210-214$

Dreistadt, S.H. 2001. Diseases, p. 69130. In: M.L. Flint (ed.). Integrated pest management for floriculture and nurseries. Publ. 3402. University of California, Oakland, CA.

Duniway, J.M. 2002. Status of chemical alternatives to methyl bromide for preplant fumigation of soil. Phytopathology 92:1337-1343.

Eayre, C.G., J.J. Sims, H.D. Ohr, and B. Mackey. 2000. Evaluation of methyl iodide for control of peach replant disorder. Plant Dis. 84:1177-1179.

Flegg, F.F.M. and D.F. Hooper. 1970. Laboratory methods for work with plant and soil nematodes, p. 5-22. In: J.F. Southey (ed.). Tech. Bul. 2. Ministry of Agriculture, Fish and Food, London.

Gilreath, J., B. Santos, T. Motis, J. Noling, and J. Mirusso. 2005. Methyl bromide alternatives for nematode and Cyperus control in bell pepper (Capsicum annuum). Crop Prot. 24:903-908.

Hanson, B.D. and S.M. Schneider. 2008. Evaluation of weed control and crop safety with herbicides in open-field tree nurseries. Weed Technol. 22:493-498.

Jenkins, W.R. 1964. A rapid centrifugalflotation technique for separating nematodes from soil. Plant Dis. Rptr. 48:692.

Mann, R., S. Mattner, R. Gounder, R. Brett, and I. Porter. 2005. Evaluating novel soil fumigants for Australian horticulture. Proc. Annu. Intl. Res. Conf. on Methyl Bromide Alternatives and Emissions Reductions. p. 34-1 to 34-4.

McKenry, M. 2005. Strategies and tactics for fumigating clay loam soils. Proc. Annu. Intl. Res. Conf. on Methyl Bromide 


\section{Research Reports}

Alternatives and Emissions Reductions. p. $37-1$ to $37-3$.

Noe, J.P. 1985. Analysis and interpretations of data from nematological experiments, p. 187-196. In: K.R. Barker, C.C. Carter, and J.N. Sasser (eds.). An advanced treatise on Meloidogyne, volume 2: Methodology. North Carolina State University Graphics, Raleigh, NC.

Ruzo, L.O. 2005. Physical, chemical, and environmental properties of selected chemical alternatives for the pre-plant use of methyl bromide as a soil fumigant. Pest Manag. Sci. 62:99-113.

Schneider, S., T. Trout, J. Gerik, A. Shrestha, and R. Rodriquez-Kabana. 2005. Methyl bromide alternatives for perennial crop field nurseries. Proc. Annu. Intl. Res. Conf. on Methyl Bromide Alternatives and Emissions Reductions. p. 41-1 to 41-4.

Schneider, S.M., B.D. Hanson, J.S. Gerik, A. Shrestha, T.J. Trout, and S. Gao. 2009.
Comparison of shank- and drip-applied methyl bromide alternatives in perennial crop field nurseries. HortTechnology 19:331-339.

Schneider, S.M., E.N. Rosskopf, J.G. Leesch, D.O. Chellemi, C.T. Bull, and M. Mazzola. 2003. United States Department of Agriculture-Agricultural Research Service research on alternatives to methyl bromide: Pre-plant and post-harvest. Pest Manag. Sci. 59:814 826.

Shrestha, A., G.T. Browne, B.D. Lampinen, S.M. Schneider, L. Simon, and T.J. Trout. 2008. Perennial crop nurseries treated with methyl bromide and alternative fumigants: Effects on weed seed viability weed densities, and time required for hand weeding. Weed Technol. 22:267-274.

Trout, T. 2006. Fumigant use in California: Response to the phase-out. Proc. Annu. Intl. Res. Conf. on Methyl Bro- mide Alternatives and Emissions Reductions. p. $18-1$ to $18-5$.

United Nations Environment Programme (UNEP). 1999. The Montreal Protocol on substances that deplete the ozone layer as adjusted and amended in London 1990, Copenhagen 1992, Vienna 1995, Montreal 1997, Beijing 1999. 23 Dec. 2008. <http://ozone.unep. org/Publications/MP_Handbook/ Section_1.1_The_Montreal_Protocol>.

Wang, D., J.M. He, and J.A. Knuteson. 2004. Concentration-time exposure index for modeling soil fumigation under various management scenarios. J. Environ. Qual. 33:685-694.

Westphal, A., A.F. Robinson, A.W. Scott, Jr., and J.B. Santini. 2004. Depth distribution of Rotylenchulus reniformis under crops of different host status and after fumigation. Nematology 6:97107. 